\title{
Fibromyalgia Syndrome: Clinical Review at the Look of the Physiotherapy Academic
}

\author{
Amanda Aguiar Barros, Hiago Montel da Costa, Daniela Santos do Nascimento, Agrinazio Geraldo \\ Nascimento Neto, Eva Coelho da Silva, Sara Resplande Magalhães, Kárita Amanda Ribeiro de Melo, Lucas \\ Coelho da Silva, Maisa Adriele Nalves da Silva, Vitória Coelho Tavares, Rafaela de Carvalho Alves, Jéssika \\ Coutinho Ribeiro, Morgane Ribeiro de Aquino Macedo, Warly Neves de Araújo.
}

\begin{abstract}
Fibromyalgia syndrome is a disease characterized by diffuse chronic pain, sleep disorder, depression and fatigue, which alters the quality of life of the individual, and acupuncture is a treatment option that already has satisfactory results in improving quality of life of individuals submitted to technique. Therefore, this study aims to highlight the benefits of physiotherapy in reducing pain pictures of individuals with fibromyalgia syndrome, evidencing the importance of physiotherapeutic treatment, simultaneously with the follow-up of pharmacological treatment. The methods used for this work were based on the methodology of the experimental factorial planning article: A brief review, published in the journal International Journal of Advanced Engineering Research and Science (IJAERS). Based on references, it is seen that the quality of life of patients with fibromyalgia syndrome is closely related to pain, stress, emotional exhaustion, depression and quality of life. Physiotherapy combined with pharmacological interventions presents satisfactory results promoting the reduction of symptoms of fibromyalgia. We can conclude that drug interventions in conjunction with physiotherapeutic
\end{abstract}

- Amanda Aguiar Barros*, Graduate student in Physiotherapy, University of Gurupi Unirg, Avenue. Rio de Janeiro. $N \circ 1585$ - Sector. Central., Gurupi, 77403-090, Tocantins, Brazil; , Corresponding Author-E-mail: amanda.1.aguiarbarros@gmail.com .

- Hiago Montel da Costa, Graduate student in Physiotherapy, University of Gurupi Unirg, Gurupi, Tocantins, Brazil

- Daniela Santos do Nascimento, Graduated in Physiotherapy, University of Gurupi Unirg, Gurupi, Tocantins, Brazil

- Agrinazio Geraldo Nascimento Neto, Graduated in Physiotherapy, University of Gurupi Unirg, Gurupi, Tocantins, Brazil

- Eva Coelho da Silva, Graduated in Physiotherapy, University of Gurupi Unirg, Gurupi, Tocantins, Brazil

- Sara Resplande Magalhães, Graduated in Physiotherapy, , University of Gurupi Unirg, Gurupi, Tocantins, Brazil

- Kárita Amanda Ribeiro de Melo, Graduated in Physiotherapy, University of Gurupi Unirg, Gurupi, Tocantins, Brazil

- Lucas Coelho da Silva,

- Maisa Adriele Nalves da Silva, Graduated in Physiotherapy, University of Gurupi Unirg, Gurupi, Tocantins, Brazil

- Vitória Coelho Tavares, Graduated in Physiotherapy, University of Gurupi Unirg, Gurupi, Tocantins, Brazil

- Rafaela de Carvalho Alves, Graduated in Physiotherapy, University of Gurupi Unirg, Gurupi, Tocantins, Brazil

- Morgane Ribeiro de Aquino Macedo, Graduated in Physiotherapy, University of Gurupi Unirg, Gurupi, Tocantins, Brazil

- Jéssika Coutinho Ribeiro, ${ }^{2}$ Physiotherapy, Educational LS - Technical School, Faculty and Post-Graduation, Pistão Sul, Taguatinga Sul-DF, 72020-111, Brasilia, Brazil.

- Warly Neves de Araujo, Graduated in Physiotherapy, University of Gurupi Unirg,, Gurupi, Tocantins, Brazil. treatments contribute to the treatment of fibromyalgia syndrome.

Index Terms-Ache, Acupuncture, Fibromyalgia, Treatment.

\section{INTRODUCTION}

Fibromyalgia syndrome is a disease characterized by diffuse chronic pain, sleep disorder, depression and fatigue, which alters the quality of life of the individual, and acupuncture is a treatment option that already has satisfactory results in improving quality of life of individuals submitted to technique [1]. In addition to being used for the relief of rheumatic diseases, acupuncture provides relief intensional cervicalgia [2]. Due to chronic pain, it is quite common for fibromyalgia to lead to abnormalities in the nervous system, changing the way patients deal with stress. Constant fatigue also generates isolation of activities, indisposition, anxiety, feeling of guilt and many other symptoms that can trigger depression [3-5].

\section{FIBROMYALGIA SYNDROME}

Non-pharmacological and anti-inflammatory interventions are important for the treatment of the individual with the syndrome, as they will be with pharmacotherapy, reduce pain and consequently provide an improvement in the quality of life of patients. The disease that mainly affects women, causing chronic pain throughout the body, of unknown origin, and discredited for a long time by health professionals [6]. It is not known what is the trigger point of fibromyalgia, out of every 10 patients with fibromyalgia, seven to nine are women. Women are affected both before and after menopause, there does not seem to be an analogy with hormones. However, there are cases in adolescents, children, and older people [735].

\section{HISTORY OF FIBROMYALGIA IN BRAZIL}

According to the committee of the American College of Rheumatology (ACR), in 1990, fibromyalgia (FM) classification criteria were defined as classification criteria tender points, with the presence in the clinical history of generalized, musculoskeletal pain [8]. 


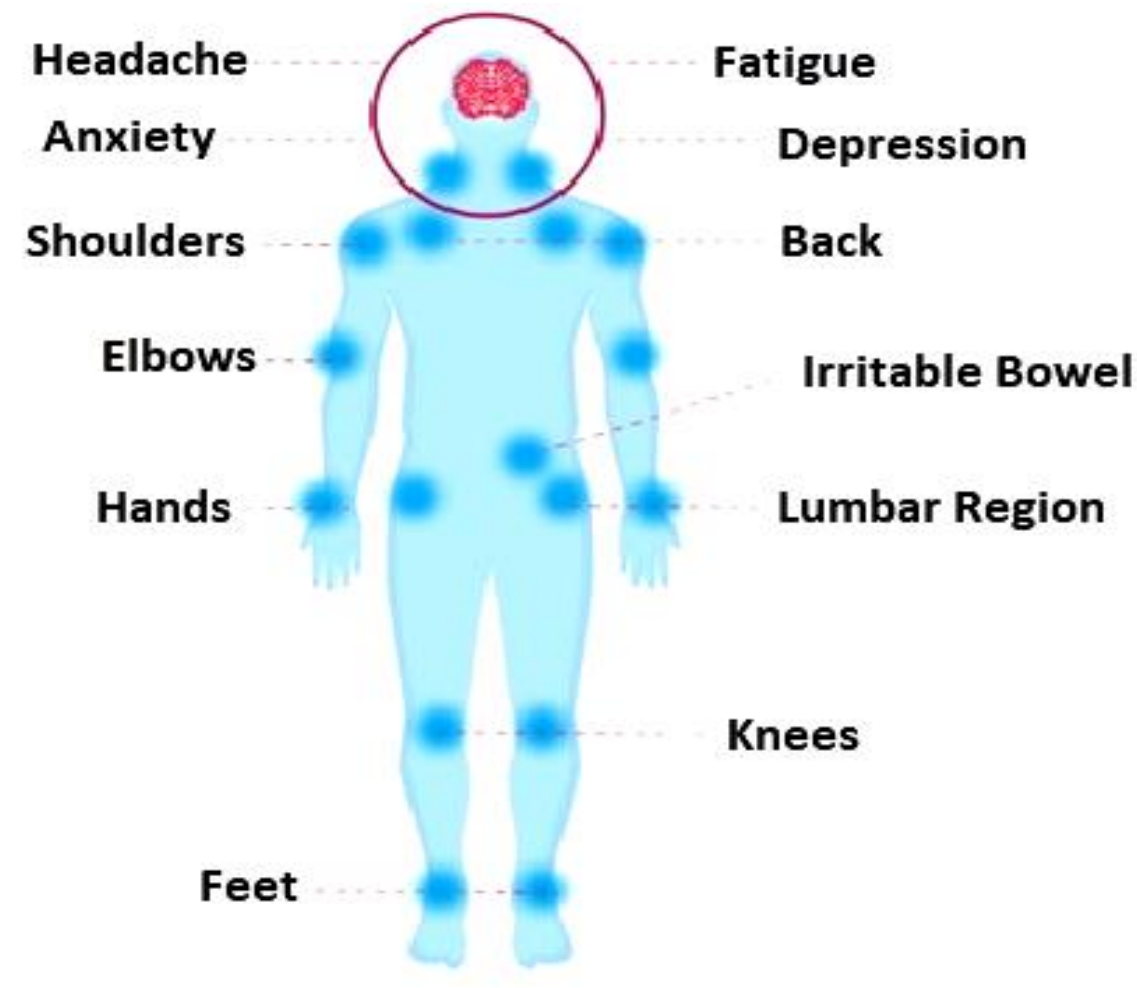

Fig 1: www.fibromialgia.com.br and reference The American Fibromyalgia Syndrome Association (AFSA), ("Fibromyalgia”, 2018) [32].

Fibromyalgia has been researched for four decades, but little is still known about its etiology and pathogenesis. Until 1970 fibromyalgia (FM) was not yet considered a defined entity when it began to emerge it was recognized as sleep disorders [9].

In 1977 the concept of FM was accepted when too many anatomical sites were described, called tender points being identified and recognized in this painful and chronic syndrome [8].

Fibromyalgia was recognized by the American Medical Association in 1987 as a disease and causing disability, 28 referring to a study conducted by Goldenberg and published in the Journal of the American Medical Association, where he reported on the findings and symptoms and decided to call it fibromyalgia $[8,10]$.

For the Brazilian society of Rheumatology SBR (2004) "the positive response criterion at least 11 points is recommended as a classification proposal, but should not be considered as essential for diagnosis".

In 2004 the Brazilian Society of Rheumatology published the first guidelines of fibromyalgia, with the objective of facilitating and directing the diagnosis and treatment of this syndrome [11].

The fibromyalgia patient has several signs and symptoms, they are, chronic pain that can cause continuous suffering to the patient generating psychoactive changes that affect the individual's perception of their well-being and quality of life, negatively interfering in the execution of their activities of daily living, leisure and work $[12,13]$.

\section{PHARMACOLOGICAL INTERVENTIONS}

The treatment of fibromyalgia is done individually and analgesic and/or muscle relaxants may be used, among other medicinal aids and non-drug interventions [14].

The pharmacological medicinal product remains a common element in most cases of FM [15]. Several drugs have already been directed to reduce FM symptoms. Cyclobenzaprine and amitriptyline in the 2016 European League Against Rheumatism or EULAR guidelines are proposed in the treatment of FM [16] and the Canadian Pain Society $(\mathrm{CpS})$ [17].

The drug duloxetine presents better evidence of efficacy for the intervention in the treatment of FM, at a dose of $60 \mathrm{mg} / \mathrm{day}$, especially when there is associated depressive morbidity, accompanied or not with anxiety $[18,19]$.

Milnacipran is a selective inhibitor that contributes to the treatment of fibromyalgia with depressive symptoms and decreased fatigue [20].

Pregabalin and gabapentin are the most commonly used anticonvulsants. Despite both having structural similarity with the gamma-aminobutyric acid neurotransmitter (GABA), they have no action on this pathway, but in voltage-dependent 
calcium channels $[15,21]$. These anticonvulsants bind to the alpha2-delta subunits of calcium channels. However, it remains unknown how they act exactly for the benefit of clinical manifestations in FM [21].

Cannabinoids, nabilone (at a dose of 0.5 to $1.0 \mathrm{mg} /$ day) and dronabinol (a synthetic form of delta-9- tetrahydrocannabinol or THC; at a dose of $7.5 \mathrm{mg} /$ day) substantially reduced levels of pain, depression, and anxiety, providing them with significant improvement in QOL [22, 23].

Melatonin (N-acetyl-5'-metoxytryptamines) and new melatonin analogs exhibited analgesic properties and significantly improves sleep with potential use as a therapeutic approach to chronic pain conditions such as FM [24]. Pain intensity decreases, there was an improvement in sleep quality, anxiety and depression were significantly improved by melatonin (3 or 5mg at bedtime) in studies with FM $[25,26]$.

Studies of melatonin and amitriptyline have shown better symptoms in relation to separate amitriptyline, but not to the isolated treatment of melatonin [27]. Thus, the noradrenérgic and serotoninergic components of the descending endogenous system of pain modulation seem to be improved by concomitant stimulation of melatoninrgic receptors, suggesting that the abnormality of the melatoninrgic system may also play a role in the pathogenesis of FM. Corroborating this theory, agomelatine, a melatonin analog with melatoninrgic receptor antagonist that has antagonistic properties of serotonin's 5-HT2C receptor, showed relief from serotonin painful symptoms, and improvement of depression and anxiety, but could not improve sleep quality in fibromyalgia patients [28, 29].

\section{FISIOTERAPEUTICA INTERVENTIONS}

Knowing the limits imposed by fibromyalgia and accepting the condition of chronically is an act that can be facilitated by health professionals, who are committed to the well-being of the human being because although the person has a healthy appearance, he manifests unclear symptoms, she has a real suffering that shakes her emotional structure and, in addition to drug treatment, patient needs psychological support to develop her adaptive resources [30]. In Brazil, a bill was approved to institute the "State Policy for the Protection of the Rights of the Person with Fibromyalgia", a chronic disease that causes and disorders in patients, by Congressman Dirceu Francisco of the Brazilian Labor Party, on 07/08/2019 [10, 31-33].

Physiotherapy plays an extremely relevant role in improving pain control and increasing or maintaining the patient's functional abilities, as well as reducing other symptoms that cause him to tribulation. Therefore, treatment is mainly aimed at reducing symptoms [34]. It was observed that the quality of life of individuals with fibromyalgia is linked to stress, depression, emotional digested and pain [35].

In 2010, in a Brazilian study, several improvements were observed in patients with fibromyalgia who underwent kinesiotherapy treatments with stretching and/or muscle strengthening, with improvement in the quality of life, improvement in fatigue, sleep, stiffness and pain [36]. In a comparative study with several types of treatment for patients with fibromyalgia, therefore, it was concluded that stretching, low-intensity aerobic exercise programs, and hydrotherapy are beneficial for patients with this syndrome because they reduce the impact of fibromyalgia symptoms and thus provide a better quality of life [37].

Physiotherapy, with the pilates technique in the treatment of fibromyalgia, is a technique that does not generate strong impacts on the joints and offers great benefits in a few weeks, results in a significant improvement in pain in the population with this pathology, despite being a chronic disease the daily practice of physical activity with pilates helps to alleviate pain and some symptoms [38].

The millennial acupuncture technique seems more effective for the benefit of acute pain than in chronic pain and manages to reduce the pain intensity in various chronic conditions, including FM [39]. Acupuncture reduces inflammation, releases endogenous opioids, and reduces anxiety. Analgesic effects of acupuncture may be associated with increased metabolized adenosine content from adenosine triphosphate (ATP) that activates adenosine A1 receptors [40].

Physiotherapy for the treatment of fibromyalgia can be applied through a number of activities that help control pain, fatigue and sleep disorders, providing relaxation and increased muscle flexibility, in addition to leading a pattern to the patient closest possible to physiological through motor activities and stretching, aiming to improve and maintain range of motion and muscle strength together [38]. Therefore, this study aims to highlight the benefits of physiotherapy in reducing pain in individuals with fibromyalgia syndrome. This bibliographic study seeks to observe that fibromyalgia is a disease that is difficult to diagnose and detect and little known, the data presented in this epidemiological study provide an inaccurate idea of the condition; which is why professionals who do not give due importance to patients' complaints, and physical pains are aggravated by the pain of misunderstanding and neglect on the part of family, friends and health professionals. It is evident not only the lack of professional preparation, in the diagnosis of this rheumatological disease, in several scientific publications, evidencing the importance of physiotherapeutic treatment, simultaneously with the follow-up of a treatment Pharmacological.

\section{MATERIALS AND Methods}

The methods used for this work were based on the methodology of the experimental factorial planning article: A Brief Review of [40], published in the journal International Journal of Advanced Engineering Research and Science (IJAERS).

To recognize the articles on the subject, a search was carried out in the databases PubMed, Sciello, Google Scholar, Virtual Health Library (VHL). Fibromyalgia syndrome is an 
unknown idiopathic pathology that mainly affects women who evidence diffuse muscle pain, chronic headache, frequent sleep disorders, tiredness, and psychic disorders among other disorders in the body Human. Fibromyalgia may present alone or correlated with other syndromes, or clinical or even rheumatological diseases, such as systemic lupus erythematosus, rheumatoid arthritis, hypothyroidism, and others. The search strategy on the subject consisted of the use of keywords in Portuguese and English: 1. Fibromyalgia,2. Pain, 3. Symptoms and 4. Quality.

Subsequently, the research to the information bases and application of the search plan were named repeated studies between the different searches. The inclusion measures of the articles were: original and research articles that conceptualize research related to fibromyalgia syndrome, rheumatic pathology that has as main characteristic muscle pains of difficult diagnosis because it is confused with several other disorders. The reason is that several rheumatic and non-rheumatic diseases may manifest themselves due to diffuse pain and chronic fatigue having several studies for pharmacotherapy, being widely used for the relief and reduction of symptoms and to provide an improvement in the quality of life of individuals, covering studies finalized in the
Portuguese, English and French language.

The deleted articles were grouped into the order: repeated, irrelevant, review, other publishing formats (edict, short communications, perspectives, letters), and other languages. In addition, manual searches were made in bibliographic references of review articles found with predetermined Keywords.

\section{RESULTS}

After removing repeated articles between the different searches, the exclusion criteria were applied, as shown in Figure 1. Of the 56 remaining articles, 40 original research articles related to fibromyalgia and pharmacological resources correlated with physiotherapy were recovered in reducing pain. Through manual search, there were no articles recovered.

The articles for use in this review, after exclusion criteria, were related and correlated homologously with fibromyalgia in physiotherapeutic treatment and pharmacological intervention.

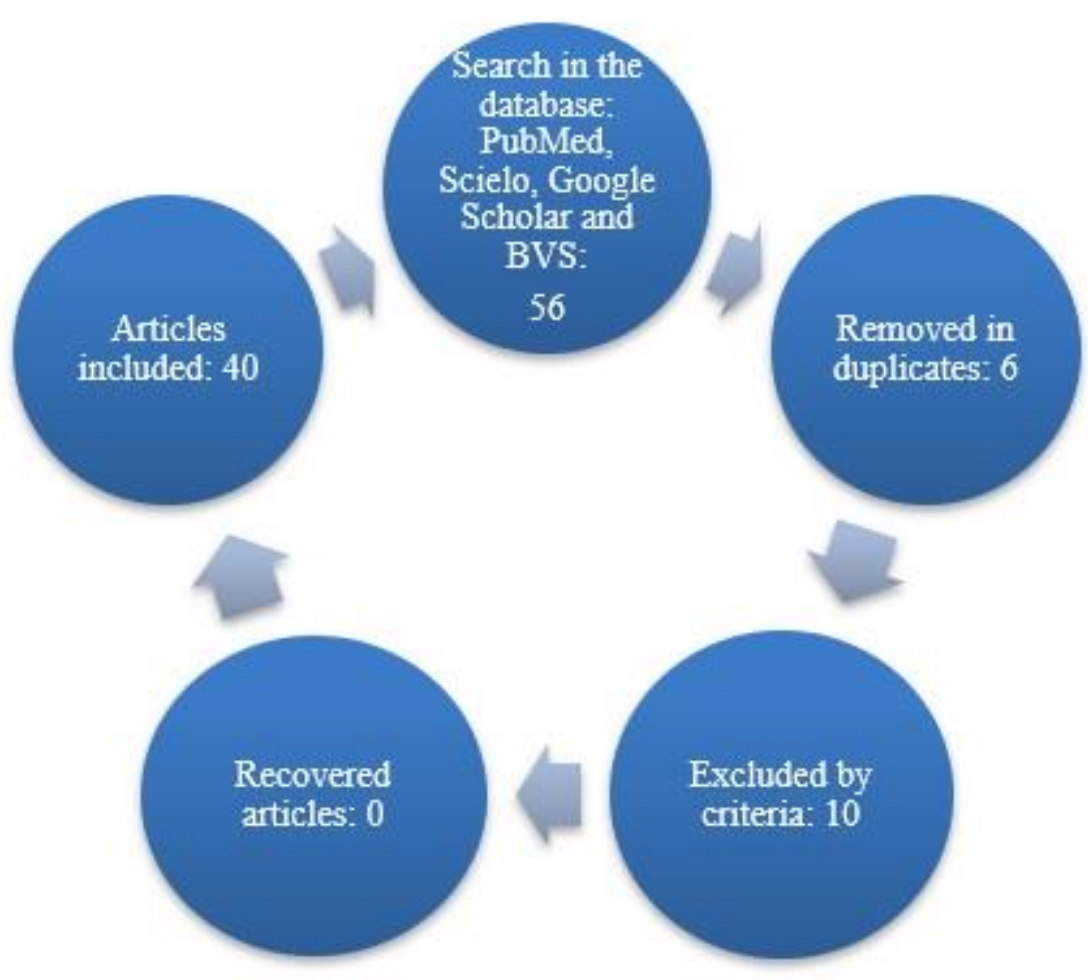

Figu2. Flowchart of identification and selection of articles. (Prepared by the authors, 2020).

\section{RESULTS AND DISCUSSION}

Based on references, it is seen that the quality of life of patients with fibromyalgia syndrome is closely related to pain, stress, emotional exhaustion, depression and quality of life. Physiotherapy combined with pharmacological interventions presents satisfactory results promoting the reduction of symptoms of fibromyalgia.
Due to the studies done, the benefits of medication use were explicit simultaneously with physiotherapy regarding the reduction of diffuse chronic pain, sleep disorders, providing increased muscle flexibility and relaxation, aiming to improve the patient's quality of life. 


\section{CONCLUSION}

We can conclude that drug interventions in conjunction with physiotherapeutic treatments contribute to the treatment of fibromyalgia syndrome. The purpose of medications and physiotherapeutic conduct is to promote the reduction of suffering, because kinesiotherapy, acupuncture, and hydrotherapy are able to intercede in mental state, improving depression, self-esteem, sleep and quality of life.

\section{ACKNOWLEDGMENT}

Indexing system and library-NORMATIZA. That during the course, it provided us with the publication of this article.

\section{REFERENCES}

[1] DE CASTRO MOURA, C. Efeitos da associação da ventosaterapia à acupuntura auricular sobre a dor crônica nas costas: ensaio clínico randomizado. 2019.

[2] ARAÚJO, W. N. DE et al. Effectiveness of acupuncture and myofascial release in analgesia of women with tensional neck pain: Systematic review. v. 6, n. 12, 30 Dez. 2019.

[3] BESSET, V. L. et al. Um nome para a dor: fibromialgia. Revista Subjetividades, v. 10, n. 4, p. 1245-1269, 2016.

[4] COELHO, C. Ansiedade e Depressão na Fibromialgia. Psicologia. PT, p. 1-16, 2016.

[5] DA SILVA, R. C. D. et al. Influência da laserterapia na dor e qualidade de vida em mulheres com fibromialgia. Revista Univap, v. 20, n. 36, p. 5-16, 2015.

[6] DIAS, C. Z. et al. Perfil dos usuários com doenças reumáticas e fatores associados à qualidade de vida no sistema único de saúde, Brasil. 2017.

[7] Fibromialgia - Definição, Sintomas e Porque Acontece. Sociedade Brasileira de Reumatologia, 31 jan. 2016. Disponível em:<https://www.reumatologia.org.br/orientacoes-ao-paciente/fibro mialgia-definicao-sintomas-e-porque-acontece/>. Acesso em: $6 \mathrm{fev}$. 2020.

[8] MEDEIROS, F. F. A sintomatologia e os aspectos emocionais de quem carrega no corpo a dor da fibromialgia: uma revisão literária. 2019.

[9] JUNIOR, M. H.; GOLDENFUM, M. A.; SIENA, C. A. F. Fibromialgia: aspectos clínicos e ocupacionais. Revista da Associação Médica Brasileira, v. 58, n. 3, p. 358-365, 2012.

[10] DOS SANTOS, L. C.; KRUEL, L. F. M. Síndrome de Fibromialgia: fisiopatologia, instrumentos de avaliação e efeitos do exercício Motriz. Journal of Physical Education. UNESP, p. 436-448, 2009. Dos, Santos LC, Kruel LF. (2009).

[11] HEYMANN, Roberto Ezequiel et al. Dores musculoesqueléticas localizadas e difusas. São Paulo: Planmark, 2010 - Pesquisa Google. Disponível em: <https://www.google.com.br/search?tbm=bks\&hl=pt-BR\&q=HEY MANN\%2C+Roberto+Ezequiel+et+al.+Dores+musculoesquel\%C3 $\%$ A9ticas+localizadas+e+difusas.+S\%C3\%A3o+Paulo\%3A+Planm ark\%2C+2010>. Acesso em: 9 fev. 2020.

[12] DOS ANJOS, R. G.; CASSAPIAN, M. R. A INTERVENÇÃO TERAPÊUTICA OCUPACIONAL JUNTO A PACIENTES COM FIBROMYALGIA/OCCUPATIONAL THERAPY INTERVENTION IN PATIENTS WITH FIBROMYALGIA
Cadernos Brasileiros de Terapia Ocupacional, v. 19, n. 1, 2011

[13] MARQUES, A. P. et al. Validação da versão brasileira do Fibromyalgia Impact Questionnaire (FIQ). Revista Brasileira de Reumatologia, v. 46, n. 1, p. 24-31, 2006

[14] BRAZ, A. DE S. et al. Uso da terapia não farmacológica, medicina alternativa e complementar na fibromialgia. Revista Brasileira de Reumatologia, v. 51, n. 3, p. 275-282, 2011

[15] KIA, S.; CHOY, E. Update on treatmensidelinesne in fibromyalgia syndrome with focus on pharmacology. Biomedicines, v. 5, n. 2 , p. 20

2017

[16] MACFARLANE, G. J. et al. EULAR revised recommendations for the management of fibromyalgia. Annals of the rheumatic $\begin{array}{llllll}\text { diseases, } & \text { v. } 76, \quad \text { n. } 2, & \text { p. } 318-328, & 2017 .\end{array}$

[17] FITZCHARLES, M.-A. et al. 2012 Canadian guidelines for the diagnosis and management of fibromyalgia syndrome: executive summary. Pain Research and Management, v. 18, n. 3, p. 119-126, 2013

[18] LUNN, M. P.; HUGHES, R. A.; WIFFEN, P. J. Duloxetine for treating painful neuropathy, chronic pain or fibromyalgia. Cochrane Database of Systematic Reviews, n. 1, 2014.

[19] ARNOLD, L. M. et al. Improvement in multiple dimensions of fatigue in patients with fibromyalgia treated with duloxetine: secondary analysis of a randomized, placebo-controlled trial. Arthritis research \& therapy, $\quad$ v. $13, \quad$ n. $3, \quad$ p. R86, 2011

[20] ARNOLD, L. M. et al. Efficacy of duloxetine in patients with fibromyalgia: pooled analysis of 4 placebo-controlled clinical trials Primary care companion to the Journal of clinical psychiatry, v 11, n. 5, p. 237, 2009.

[21] ARNOLD, L. M. et al. An evidence-based review of pregabalin for the treatment of fibromyalgia. Current medical research and opinion v. 34, n. 8 , p. $1397-1409,2018$.

[22] [22] WEBER, J. et al. Tetrahydrocannabinol (Delta 9-THC) treatmen in chronic central neuropathic pain and fibromyalgia patients: results of a multicenter survey. Anesthesiology research and practice, v 2009,2009

[23] WARE, M. A. et al. The effects of nabilone on sleep in fibromyalgia: results of a randomized controlled trial. Anesthesia \& Analgesia, v 110 , n. 2, p. 604-610, 2010

[24] SRINIVASAN, V. et al. Potential use of melatonergic drugs in analgesia: mechanisms of action. Brain research bulletin, v. $81, \mathrm{n}$ $4-5$, p. 362-371, 2010

[25] DE ZANETTI, S. A. et al. Melatonin analgesia is associated with improvement of the descending endogenous pain-modulating system in fibromyalgia: a phase II, randomized, double-dummy, controlled trial. BMC Pharmacology and Toxicology, v. 15, n. 1, p. 40, 2014

[26] HUSSAIN, S. A.-R. et al. Adjuvant use of melatonin fothe $r$ treatmen of fibromyalgia. Journal of pineal research, v. 50, n. 3, p. 267-271, 2011

[27] SCHUMACHER, M.; PASVANKAS, G. Topical capsaicin formulations in the management of neuropathic pain. In: Capsaicin as a Therapeutic Molecule. [s.1.] Springer, 2014. p. 105-128.

[28] BRUNO, A. et al. Agomelatine in the treatment of fibromyalgia: a 12-week, open-label, uncontrolled preliminary study. Journal of clinical psychopharmacology, v. 33, n. 4, p. 507-511, 2013.

[29] CALENDAR, E. P. et al. Agomelatine for the treatment of patients with fibromyalgia and depressive symptomatology: an uncontrolled, 12-week, pilot study. Pharmacopsychiatry, v. 47, n. 02, p. 67-72, 2014 
[30] MARQUES, A. P.; ASSUMPÇÃO, A.; MATSUTANI, L. A. Fibromialgia e fisioterapia: avaliação e tratamento. [s.l.] Editora Manole, 2007.

[31] Dirceu Franciscon protocola projeto que dá apoio às pessoas com fibromialgia. Disponível em: <http://www.al.rs.gov.br/agenciadenoticias/destaque/tabid/855/Id Materia/317811/Default.aspx>. Acesso em: 6 fev. 2020

[32] Fibromialgia: sintomas e sua relação com a depressão | Vittude. Blog Vittude, 17 set. 2018. Disponível em: <https://www.vittude.com/blog/fibromialgia-sintomas-depressao/>.
Acesso
em:
10
fev.
2020

[33] OLIVEIRA JÚNIOR, J. O. DE; ALMEIDA, M. B. DE. O tratamento atual da fibromialgia. BrJP, v. 1, n. 3, p. 255-262, 2018.

[34] BRUM, L. M. A qualidade de vida dos professores de ciências e a relação das suas disciplinas com o cotidiano dos alunos em uma escola pública no interior do Rio Grande do Sul. $\mathrm{PhD}$ Thesis-[s.1.] Universidade Federal de Santa Maria, 2012.

[35] ALVES, R. DE C. et al. Sleep Quality, and Perception of the Disease in Fibromyagic Patients at the School of Physiotherapy Clinic of Gurupi University. Journal of Advances in Medicine and Medical Research, p. 1-14, 2019.

[36] BARBOSA, J. M. EFEITOS DE UM PROGRAMA DE TREINAMENTO RESISTIDO OU DE FLEXIBILIDADE NA FORÇA ISOTÔNICA, NA DOR E NOS ASPECTOS PSICOLÓGICOS EM MULHERES COM FIBROMIALGIA. 1. p. 85, 2013.

[37] KONRAD, L. M. Efeito agudo do exercício físico sobre a qualidade de vida de mulheres com síndrome da fibromialgia. 2005.
[38] LADVIG, R. P.MASELLILI, M. R.; ALBUQUERQUE FERREIRA, D. M. EXERCÍCIOS BASEADOS NO MÉTODO PILATES NO TRATAMENTO DE PORTADORAS DE FIBROMIALGIA: RELATO DE CASOS. Colloquium Vitae. Anais...2016.

[39] DEARE, J. C. et al. Acupuncture for treating fibromyalgia. Cochrane Database of Systematic Reviews, n. 5, 2013.

[40] OLIVEIRA, M. DE et al. Experimental Planning Factorial : Briefef Review. International Journal of Advanced Engineering Research and Science (IJAERS), v. 6495, n. 6, p. 166-177, 2018.

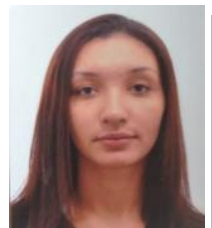

Hello, my name is Amanda Aguiar Barros, I'm 21. I'm an undergraduate student in the 6 th period of physiotherapy at the University of Tocantins-Unirg. I currently have an article published on Fibromyalgia Syndrome and I intend to make more publications of articles.

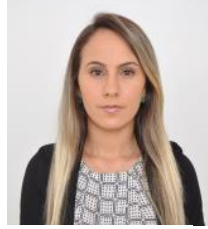

Hello, my name is Eva Coelho da Silva, I am 25 years old, I was born on April 29, 1994 in the city of Gurupi, state of Tocantins, Brazil. I am a graduate student of the 6th period of Physiotherapy at the University of Tocantins- Unirg.

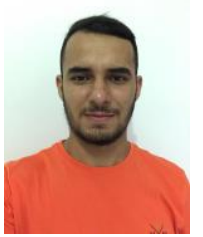

Hello, my name is Hiago Montel da Costa, I am 25 years old, on 03/23/1994 in Carolina Maranhão Brazil, I have a degree in physiotherapy from the University of Tocantins, currently during my graduation I have internships at Hospital Regional and at physiotherapy from unirg, in order to acquire more knowledge. 